\title{
Gandharva and Their Livelihood in Baglung District, Nepal
}

\section{Article Info}

Received: 25 September, 2021

Received in revised form: 11 December, 2021

Accepted: 16 December, 2021

Available online: 30 December, 2021

DOI: https://doi.org/10.3126/dsaj.v15i01.41929
Saroj Raj Panta

Dhawalagiri Multiple Campus, Tribhuvan University, Nepal

\begin{abstract}
This paper focuses on the changing livelihood of the Gandharva, a minority people of Baglung District, Nepal. This research adopts qualitative data based on observations, case studies, in-depth-interview, and a literature review. The data have been thematically analyzed and interpreted. Gandharva usually follow their traditional methods of singing and storytelling (Gainegeet), playing sarangi. Sarangi is a traditional musical instrument. Today many of them have adopted agriculture, carpentry, mason, driving, and labor jobs for their livelihood. They are forced to change their livelihood due to limited income insufficient to fulfill their basic needs. Switching to other occupations is not easy. They face lots of difficulties. Due to globalization and modernization, modern songs, radio, television, youtube, social media are getting popular than songs of Gandharva. People today rarely listen to Gandharva's songs and Sarangi, which is on the verge of extinction. This paper explores their lives closely to understand their difficulties and struggle for survival.
\end{abstract}

Keywords: gandharva, livelihood, poverty, traditional occupation, change, sarangi

\section{Introduction}

Nepal has socio-cultural diversity, with 125 castes and ethnic groups living together (Central Bureau of Statistics[CBS], 2011). It has various languages and cultures, resulting in a diverse and unique culture (Bista, 1989). Gandharva is one of Nepal's minority Dalit caste groups that played a vital role in Nepal's national identity, which its cultural and ethnic diversity has always shaped. According to Bishwokarma (1996) Sudra in the Sanskrit language means foreign, separate people of outside. According to Brahma Puran, Sudra was born from the foot of Lord Brahma. However, from time and again, the Sudra is defined differently by different people based on time, context, and desire.

Gandhava's performing arts can contribute to the harmony between groups of people through the musical instruments Sarangi. Baglung is popular for Gandharva songs. The Gandharvas were nomadic musicians who played traditional folk and historical songs. Sarangi had been the iconic musical instrument of the Gandharva as a means of earning to meet their basic needs. Gandharvas face problems of livelihood support through Sarangi and songs. This study focuses on documenting their changing livelihood.

Gandharvas are leaving their traditional occupations in Baglung (Panta, 2074 BS). They are treated as untouchable and behave differently by other castes. Gandharvas of Baglung, who falls below the poverty line, give up their traditional occupation. This research tried to find answers to two research questions: what is the livelihood condition of Gandharvas? And why do they change in their traditional occupation?

\section{The Study Area}

Located in Gandaki Province, the Baglung District is known as mini Nepal, rich in culture and identity (District 
Development Committee [DDC], 2074 BS). The district has four municipalities and six rural municipalities with a total area of 1784 square kilometers. The total population of Gandharva in Nepal is 3,287, out of which 203 Gandharvas live in 40 households in Baglung municipality-12, Amalachaur, Galkot municipality- 3, 4, Hatiya, Baglung municipality-3, Baglung, Jaimini municipality-6, Payunthanthap, Bihunkot Baglung. Gandharva migrated to these areas for their livelihood.

\section{Methods}

This study is descriptive and analytical based on field observation, interview, questionnaire, and case study. A questionnaire survey, field observation, case study, and conducting informal discussion were the basis of primary data. A literature review was done for secondary data. National census reports, DCC, Municipality profiles, articles, and newspapers relating to the Gandharva community were reviewed. Observation, interviews, questionnaire surveys, and case studies were used to understand their traditional occupation and livelihood strategy.

\section{Findings}

\section{Population of Gandharva}

The total population of Gandharva was 6,791 across Nepal. Baglung had a total population of 2, 68, 613 (CBS, 2011).The total number of Gandharva was only 203 (0.076 percent) of the total population of Baglung, making the tribe endangered. Similarly, there were 1, 56 Gandharva in Baglung which later increased to 203. Baglung Municipality-12, Amalachaur, Galkot Municipality-3, Hatiya, Baglung Municipality-3, Baglung Jaimini Municipality-9, Payunthanthap, Kathekhola Rural Municipality, 6 Bihunkot. Of the five locations, Galkot has a higher number, and Kathekhola Rural Municipality, Bihunkot has fewer. Baglung Municipality-12, Amalachaur was their main settlement area, but they migrated to other places for livelihood and better opportunities.

\section{Occupation and Livelihood}

There are 40 households of Gandharva in Baglung. Out of them, only eight households follow their traditional occupation. Gandharvas practiced traditional singing with Sarangi to collect food and practice agriculture. Thirtytwo households do not follow a traditional singing culture because their siblings are not interested in singing for a living. Bishnu Gandharva shared that singing does not fulfill their daily basic needs.

The new generation of Gandharva adopts professions that make their life easier besides singing for a living (Neupane, 2064 BS). Sources of entertainment such as mobile, television, computer, social media, and the internet have threatened their culture (Panta, 2077 BS). Gandharva also work as daily wage labor for their livelihood in Baglung. They are also engaged in agriculture, carpentry, mason, driving, and labor. Though they are engaged in other sectors, their source of income is not satisfactory because of not having a regular job in the periphery and lowwages, making them economically and socially backward.

Sangit Gandharva (32 years) was born and raised in Baglung Municipality-12. Earlier, the brothers of the Gandharva community played the Sarangi at the door of Bista singing Lahure, Cheli, and incident songs. In return, they got food, grains, money, and clothes to support their households. The brothers used to go to Karkha singing with their grandparents. Despite his want to continue playing Sarangi, he was forced to move to Mandras, India. He also decided to go because his fathers and brothers were not well-respected, who follow tradition singing occupation. He got married and now has two sons and a wife. He later went to Saudi Arabia to earn for his children but returned after 15 months due to Covid 19. He is worried about the future of his son and daughter. Modern technology like radio, television, newspapers and mobile phones has reduced the value of Karkha songs and traditional instruments like the Sarangi. Caste discrimination is another major cause of loss of use of Sarangi because the one who plays such traditional instrument is considered lower cast by other casts of the society.

Table 1: Population of Gandharva

\begin{tabular}{|c|l|c|c|c|c|}
\hline S. No. & Place & Male & Female & Total & Percent \\
\hline 1 & Baglung Municipality-12, Amalachaur & 26 & 34 & 60 & 29.56 \\
\hline 2 & Galkot Municipality-3, Hatiya & 51 & 47 & 98 & 48.27 \\
\hline 3 & Baglung Municipality-3, Baglung & 12 & 10 & 22 & 10.84 \\
\hline 4 & Jaimini Municipality- 9, Payunthanthap & 8 & 4 & 12 & 5.91 \\
\hline 5 & Kathekhola Rural Municipality, 6 Bihunkot & 7 & 4 & 11 & 5.42 \\
\hline & Total & 99 & 104 & 203 & 100 \\
\hline
\end{tabular}

Source: CBS, 2068 (2011) 


\section{Use of Resources for Livelihood}

Out of 40 households, eight households are landless, and the 32 households have only Bari. Their lands are not fertile, have low productivity, and are difficult to sustain. Gandharvas do not have regular sources of income, fertile agricultural lands, and physical capitals such as housing, tools, and instruments. The economic condition of the Gandharvas is poor. Gandharvas depend on forest resources for making Sarangi, firewood, fodder, fruits, medicinal herbs, and materials for building houses. Gandharva women collect leaves, firewood, and other necessary things from the forest for cooking. Sangit Gandharva shared that Gandharvas would not survive only by following their tradition of playing Sarangi. Today, Gandharvas migrate for job employment in India, and Saudi, also works as labor in villages and towns.

\section{Health Sanitation and Livelihood}

Health is wealth. A balanced diet is required to be healthy. For Gandharvas taking a balanced diet is not a priority. They spend money on food, clothes, smoking, alcohol, and celebration. The household environment is not clean, and they fall prey to different diseases. According to Durga Prasad Sharma, the health in charge of that area, the frequency of their visit to health post has increased compared to a few years back. They have become conscious of their health. However, they could not save money for health which is spent on supporting basic needs.

In comparison to other castes, the number of old Gandarvas is few. It might be because of poor nutrition, plenty of rest, and a good environment required staying healthy. Male prefers to drink alcohol and smoke cigarettes than spend on a proper diet. Females' health condition is better than males, but poor nutrition and lack of balanced diet cause them ill.

\section{Socio-cultural Life and Changing Status}

Socio-economic status of Gandharvas is changing. They now have access to mobile phones, FM radio, and televisions for information and communication. Many of them prefer labor both in-country and abroad to support their livelihood. At present, they are willing to be united for their rights and in search of opportunities as it is difficult to support their life through traditional occupation. They practice two types of marriage: family arranged and/ or finding their partner. Dalit communities also practice inter-caste marriage. Gandharvas celebrate naming ceremony on the $11^{\text {th }}$ day of the baby's birth. After death, the body is either burnt or buried. They perform funeral rites for $13^{\text {th }}$ days. Every year Sharadha annual ceremony is performed for the peace of the departed soul. Although old generations follow traditional culture, new generations practice it differently.

Gandharvas enjoy modern food and drinks. In the past, they ate dhindo, aato, roti, khole, sisno (Stinging nettles). Now, the Gandharva community has increased the use of meat, bread, and rice. They take loans to go to India, Japan, and other Arabian countries. Two people from the Balewa area have gone to Japan to work. Some families take a loan to celebrate festivals. The poor housing has been replaced by s mud houses, with a single-story and a thatched roof. They practice rites and rituals as other Hindu castes such as naming ceremony, feeding ceremony, upanayana (bratabandha) ceremony, marriage ceremony, death rituals, annual ceremony (Saradha). They celebrate different festivals like other Hindu people, such as dashain, tihar, holi, janaipurnima, maghe sakranti, (lutofalne) Sharawan sakranti, teej, shivaratri, Chaitre dashain. In the Gandharva community, males are treated as the head of the family who makes entire household decisions.

\section{Education}

In the past, Gandharvas did not send children to schools. Instead took their kids to traditional singing and the field to work. Being a dalit, they did not have equal access to culture, politics, education, and role in decision-making. Devi Gandharva says that currently, children of Gandharva in Baglung go to school. Parents now have shown interest in sending their children to schools. Some of them have passed SLC/ SEE, CMA, class 12, and studying bachelor level. Although children of Gandharva study at the basic level, they face problems studying at a higher level due to poverty. There are few educated Gandharvas, but they are not getting opportunities to study further and work due to poverty.

\section{Costume}

Clothing patterns and decorations have also changed in the Gandharva community. In the past, male Gandarvas wore kachhad, bhoto and pheta. Nowadays they have different attaire, they wear pants, shirts, T-shirts, jackets, half-pant, Istkot, Topi, shoes, slippers, etc. Women used dhoti, Cholo, Lungi, but nowadays they wear Sari, Blouse, Lungi, Cholo, kurtha, sarawal, rings, chura, pote, sindur, sandals with modern cosmetic items. Shirts, pants, and jackets are getting popular among men. Saris, Blouse is popular among married women, and Suruwal, Kurtha, Shirt, T-shirts, and Maxi are popular among unmarried. According to Sangit Gandharva and Kamala Gandharva, new generations try to adopt fashionable costumes, but they cannot buy proper costumes due to their poverty. Socio-Cultural Relations to other communities

In the past, there was caste discrimination that is why its impact was there in the Gandharva community. There was discrimination between the so-called upper 
caste and lower caste people. Due to untouchability, their lifestyle was difficult. According to Surya Lal BK, one of the respondents of Amalachaur, Gandharvas were treated as Dalit people who face discrimination. Gandharvas do not have equal access to culture, politics, and decision-making levels. However, there is some improvement in their social relationship. Sita Gayak a women's health volunteer from the Gandharva community, says Gandharvas have helped other people in society by spreading awareness through songs, music, and participation in the protection of public places, forest conservation. The Gandharvas deals with other castes during income generation and economic transactions. In the production process, plowing, digging, and planting crops depend on other castes. Gardarvas are not politically active, but they practice voting rights. Politicians are directly or indirectly associated with the so-called rich, Brahmin, Kshatriya, Magar, Damai, Kami Sarki, and other castes. Panta (2074 BS) found that Gandharvas go to the village to make relationships for reconciliation melapat labor sharing, entertainment, Folk music relationships with other castes people. Gandharva caste has its own identity, to entertain the people of other castes through sarangi, to convey various events in the country and abroad to the villagers through songs, to convey various social messages.

\section{Sarangi (Violin), Cultural Practice and Livelihood}

Gandharvas are skilled in playing a musical Sarangi instrument for their livelihood. Their main musical instruments are 'sarangi' and 'arwajo'. Gandharvas also performs dance (Panta, 2020). Gandharvas are famous for Tarbare Nritya (Sword Dance), Jaimalpatta Nritya, and Ratyauli Nritya. In Tarbare Nritya, they dance with a sword. This dance reflects the war scene to show bravery and give information about war or conflict. In 'Jaimalpatta Nritya', they dance in a group playing four Sarangis, two arwajos, two madals, and two mujuras. In addition, Ratyauli Nritya is performed by women in marriage to share their joys. They perform these types of culture for livelihood and entertainment. During the field study, 2076, the participants asked what topics are included in the song. Respondent Mr. Bishnu Gandharva said that earlier, Gandharva used to sing about the events of the country and abroad and Lahure in recent times, women's pain and contemporary issues have been raised through their songs for livelihood.

The Sarangi is a bowed, short-necked string play traditionally by Gandharvas. Sarangi initially had four primary metal strings and a break even with several major tuning pegs. The instrument had eleven strings, the tuning pegs for which are set in two columns along the side of the instrument's neck. It is alluringly trimmed with ivory. The strings passed through gaps within the ivory angle themes that have been trimmed within the wooden body of the Sarangi. The underside of the neck is open to encourage simple re-stringing. The head of the instrument, which is in simple reach of the hand holding the bow, is utilized to store wax or tar for the bow. The name of the musical instrument Sarangi is related to Lord Vishnu. It is derived from Lord Vishnu's bow, which may have been called Sarangi because it was played with a bow(Kadel, 2007).

Sarangi is the main musical instrument and base of income for the Gandharvas. Sarangi is made from khirro (tallow tree) wood (sapium insigne), the leather of the goat's intestine. Nowadays Nylon rope is used in place of the intestine of a goat. Gandharvas play Sarangi in various songs. It is one of the main means of attraction of tourists. The price of Sarangi is about Rs 10000 , but again it is difficult to make (Panta, $2070 \mathrm{BS}$ ).

According to Ranade(1989) the word Sarangi is a combined of two words: Sadrangi in Persian, which is "hundred" and pitiful in Persian ("bai") colored') is harmed as Sarangi. The term sehrangi implies three melodic strings. In any case, the foremost common, well-known historical underpinnings are that Sarangi is inferred from sol rang ("one hundred colors"), showing its versatility to different vocal styles, adaptable adjustability, and the capacity to deliver a huge number of tonal and passionate subtleties. Foreign scholars have also studied and researched Gandharva's songs and music. Maconald (1975) has described various Gandharva songs.

\section{Changing Livelihood and Strategy of Gandharva}

Karna Bahadur Gayak, an older man of the Gandharva community, says that wherever Gandharva moved from place to place by singing, village people called them Gahine or Gayak. The identity of Gandharva is associated with art and music as well as livelihood. In the past, Gandharvas moved from one place to another with their musical instrument Sarangi for their livelihood, which helped them survive. They explored information, the message of war, incidents as well. Gandharva sing songs related to their own experiences of daily life, poverty, misery, and exploitation. They earned little money and collected seasonal food grain, sharing joys and sorrows in their villages and nearby areas through their songs for livelihood.

Gandharvas are called Mijar, Gandhari, Singer, Sarangidai, Nepali, based on their occupation adopted by forefathers for their livelihood. Bhattari (2007) explained the importance of the Gandharvasto bring change in society. He concluded that the Gandharvas had played a vital role in exploring the sorrow, problems, and reality of Nepali people through songs from one place to another. He suggested changing their name from Gaine or Gayak to Gandharva for their livelihood. Nowadays, Gandharvas prefer to call themselves Gandharvas or singers. The singers say that they sing in their language (Bandhu \& Divas, 2064). Although Gandharvas have traditional culture, values, norms, and customs, they face difficulty sustaining their livelihood through singing. Gandharvas have changed their professions for their livelihood. They 
choose foreign labor migration and skillful jobs such as carpentry, mason, driving, and poultry farming.

\section{Discussion}

Gandharva often is known as the Gaine. This group is passionate about advancing and preserving Nepali music. In the village, they sing songs in the traditional style. The Gandharva are Dalits who belong to the Indo-Aryan ethnic group living in the central, hilly region of Nepal. They are called traditional musicians and traveling musicians. Gandharva followed traditional occupation for their livelihood and received donations in food, money, or other necessary things. Gandharva uses the Nepali Sarangi, (violin) as their main musical instrument (Kadel, 2007). Gandharvas have made outstanding contributions to the progress of Nepali music and dance. All Gandharvas agree that they are descendants of Gandharva Rishi. Many gatherings safeguard the genuine soul of Nepali music. One of the cultural gatherings is Gandharva, called Gaine. This gathering has an incredible commitment to the advancement and conservation of Nepali music. They sing the tune of their encounters brimming with distress, hopelessness, neediness, and abuse. Gautam, R. and Thapa Magar, A. K. (1994) have categorized gaine as untouchable castes of Nepal such as Gaine, Dom, Badi, Kami, Musahar, Sarki, Halkhor, etc. Sharma, Chhetri, and Rana (1994) have stated about caste-based discrimination and its related matters. In 1984, the Ministry of Labor and the Social Welfare Council studied the Gandharva castes of Kaski and Lamjung districts. According to the study, their social, educational and economic condition was very poor and the government was immediately advised to make special efforts for their upliftment. There are many problems on the livelihoods of Gandharva people in Baglung who face caste-based discrimination, poor economy, health, education, and political representation.

Gandharvas are not interested in following their occupation due to less income. Gandharvas migrate to city areas or abroad for jobs. Civil code (1963 [2020 BS]) has eradicated the country's caste system, but it is only in the document, not in practice. So, Dalit community people like Gandharva face the problem of discrimination. Because other casts do not accept food prepared by dalits, they could not run hotels, restaurants, and other food-related businesses.

They have Gujara system and still, the situation is unchanged in old generation but the new generation is trying to change. The information and data gathered revealed that they are physiologically or hereditarily capable, but they need financial support. The new generation of the Gandharva community is not interested in adopting the traditional profession. Gandharvas and their instruments should be valued. They should be trained and involved in poverty elimination and sanitation improvement programs. They should be provided with better education.

\section{Conclusion}

The Gandharvas are endangered in traditional occupation, caste under the Dalit community. Gandharvas are economically poor, politically backward, and affected by economic, social, cultural, and political differences. Being Dalits, they cannot run a hotel restaurant business or shop in the village for economic gain and livelihood here. Despite gradual improvements in access to education, Gandharvas have not held government jobs and secured their position in policy-making. In terms of cultural significance, the Gandharvas cannot earn money by attracting foreign tourists through Karkha and Zhaure songs that could support their livelihood.

Traditional singing and its income make it difficult to meet their basic needs. Thus, the new generation is not interested in following traditional occupations. They are leaving the traditional singing profession and adopting diverse occupations. Due to the previous generation's inferiority and the lack of development of new skills for the new profession, young people have migrated to India and other Gulf countries to earn their livelihood. Poverty has a far-reaching impact on their lives by lacking adequate food, education, health, and other basic needs.

\section{Acknowledgments:}

I would like to express my deep and sincere gratitude to Dr. Man Bahadur Khattri and Mr. Kanchan Mani Dixit, who encouraged and guided me to conduct this research and to make this work valuable and publishable. I am grateful to the research respondents and participants for their supporting and cooperating in this research issue. All the respondents and Gandharvas of Baglung Municipality-12, Amalachaur, Galkot Municipality3, Hatiya, Baglung Municipality-3, Baglung Jaimini Municipality- 9, Payunthanthap, Kathekhola Rural Municipality, 6 Bihunkot provided me valuable time and shared their joys, sorrows, and experiences on their livelihood. I am thankful to Mr. Kamal Sharma, Mr. Dev Bahadur Chhetri, Mr. Durga Prasad Sharma, Mr. Suryalal BK, Mr. Sangit Gandharva, Mrs. Kamala Gandharva, Mrs. Sita Gandharva, Mr. Bishnu Gandharva, and Miss. Devi Gandharva. Special thanks to the anonymous manuscript reviewers, for their constructive comments and insightful feedback to make this work precious.

\section{Funding:}

The author has not received any funding for this research from any institution.

\section{Consent for Publication:}

Not applicable. No any institutional approval for the research is required

\section{Conflict of interest:}

The author does not have any conflict of interest concerning 
this research

\section{Ethical Conduct of Research}

I declare that this research has been conducted ethically and assured of the confidentiality of the respondent and participants required for social research.

\section{References}

B. K, T. B. (1996). Caste discrimination in Nepal and history of Bishworkarma. Self.

Bhattari, B. R. (2007). Caste discrimination. n.p.

Bista, D.B.(1991). People of Nepal. Ratna Pustak Bandar.

Bista, D.B. (1972). People of Nepal (3 ${ }^{\text {rd }}$ ed.). Ratna Pustak Bhandar.

Bista, D.B. (1989). The structure of Nepali Society. Ratna Pustak Bhandar.

Bor, J. (1987). The Voice of the Sarangi. National Centre for the Performing Arts Quarterly Journal 15(3-4).

Central Bureau of Statistics [CBS] (2011). National population and housing census 2011 (National Report).

Civil code (1963). Nepal kanunkitab byabastha samiti: Babarmahal.

District Development Committee [DDC]. (2017). District Profile District Coordination Committee, Baglung.

Gautam, R., \& Thapa- Magar, A. K. (1994). Gaine: Tribal Ethnography of Nepal. (Vol. 2). Book Faith India.

Goh, C. B. (1989). The Relevance of history to our lives today. Teaching and Learning, 10 (1).

Gautam, R. \& Thapa Magar, A. K. (1994). Tribal Ethnography of Nepal. Oxford University Press.

Gramsci, A. (1996). Selections from prison notebooks. (Haore \& GN Smith, trans.). Longman.

Prased, R. (2007). Musical instruments of Nepal. Nepali Folk Instrument Museum.

Macdonald, A. W. (1975). The Gaine of Nepal: An essay on the ethnology of Nepal and South Asia. Ratna Pustak Bhandar.

Nepal Government (1963). Civil code of Nepal (2 ${ }^{\text {nd }}$ ed.). Pairabi Publication.

Nepal Government (2015). Constitution of Nepal. Makalu Publication Home.

Neupane, K. (2064). Gandhav's Performing Folk Art: Continuity and Change, Janapagyamanch: JMCU.

Pandey, M. (2063). Gaidharva and Dalits of Nepal. Pairavi Prakashan.

Panta, S.R. (2062). Westernization and its impacts. Bal Bagaicha, Vol. 4. AAHSS, Baglung.

Panta, S.R. (2074). Gandhava and endangered Sarangi. Nagarik Dainik Paschimeli Kathmandu, 2074/11/09.

Panta, S.R. (2070 BS). Gandharva and Their Livelihood: A study in Hatiya VDC, Baglung, Nepal. Pragyna Sarathi, 12(12). TUTA, DMC, Baglung.

Panta, S. R. (2021). Rodhi cultural practice of Gurung community in Ghandruk. Sirubari Tourism: A Study,
Tribhuvan University, Dhaulagiri Multiple Campus Department of Sociology Anthropology, BA third year, Research Group, 2018.

Ranade, A. (1989). Joep Bor. The Voice of the Sarangi: An Illustrated History of Bowing in India. 154 pp., discography, notes, illustrations, photographs. National Centre for the Performing Arts: Quarterly Journal XV 3-4; XVI 1. Yearbook for Traditional Music, 21, 121-122.

Sharma, K., Chhetri, G. \& Rana, S. (1994). A modest study of the current socio-economic situation of the lowest caste and tribal groups in Nepal (Report no.). Save the Children US.

SWC (1984). Social welfare council report.

Thapa, D. R. (1963). Gandak Suseli. Royal Nepal Academy.

Saroj Raj Panta https://orcid.org/0000-0002-5745-6100 is an M. Phil. scholar at Nepal Open University and works as a course contact teacher at the Department of Sociology/Anthropology, Dhawalagiri Multiple Campus, Baglung, Tribhuvan University, Nepal. He also served as a teacher and Lower Secondary Level Coordinator at Amrit Adarsha Higher Secondary School for 21 years. His areas of research interest are culture, gender, ethnicity, transformative learning and disaster management. He was awarded National Education Award, by Government of Nepal 2069 BS and District Education Prize 2066 BS by District Education Office, Baglung.

Email: Sarojpanta.sp84@gmail.com 